\title{
A re-examination of the Pliensbachian and Toarcian Ostracoda of Zambujal, west-central Portugal
}

\author{
IAN BOOMER ${ }^{1}$, NIGEL R. AINSWORTH ${ }^{2}$ \& JOHN EXTON ${ }^{3}$ \\ ' School of Environmental Sciences, University of East Anglia, Norwich NR4 7TJ, UK. \\ 22 Millers Rise, St Albans, Hertfordshire AL1 1QW, UK. \\ ${ }^{3}$ Hamilton Oil Company Limited, Devonshire House, Piccadilly, London W1X 6AQ, UK.
}

\begin{abstract}
Pliensbachian and Toarcian Ostracoda first described by Exton (Geological Paper, Carleton University, Ottawa, 79: 1-104 1979) from the Lusitanian Basin, west-central Portugal have been re-examined. As a result, a greater diversity in the Ostracoda ( 80 species) is now recognized. Two species are newly described (Eucytherura zambujalensis sp. nov., Ektyphocythere mediodepressa sp. nov.) from the marls and calcareous shales of the Maria Pares Hill section near the village of Zambujal. Poor preservation precludes a complete taxonomic review of the present material. Five ostracod zones are proposed; Gammacythere ubiquita-Ogmoconchella gruendeli Zone, Polycope cerasia-Polycope cincinnata Zone, Liasina lanceolata-Ogmoconcha convexa Zone, Bairdiacypris rectangularis-Kinkelinella sermoisensis Zone, and Cytherella toarcensis-Kinkelinella costata Zone. Although the ostracod assemblages possess strong similarities to those described from Northwest Europe, some of the Zambujal assemblages are dominated by the genus Polycope. A marked faunal turnover, in association with the extinction of the Metacopina occurs in the lower Subzone of the tenuicostatum Zone of Lower Toarcian age. These faunal events are discussed in relation to changing environmental conditions. J. Micropalaeontol. 17(1): 1-14, April 1998
\end{abstract}

\section{INTRODUCTION}

In the light of more recent studies and with a view to detailing major faunal changes during this interval, a review of the Pliensbachian and Toarcian Ostracoda first described by Exton (1979) from the Zambujal section of west-central Portugal has been undertaken by the present authors. Since the earlier work of Exton, over 40 papers have been published on Pliensbachian and Toarcian Ostracoda of northwest Europe. These include Herrig (1969 et seq.), Knitter (1983, 1984), Park (1987, 1988), Knitter \& Riegraf (1984), Exton \& Gradstein (1984), Riegraf (1984, 1985), Dépêche (1985), Bate et al. (1984), Donze (1985), Ainsworth (1986 et seq.), Ainsworth \& Horton (1986), Bodergat \& Donze (1988), Boomer \& Lord (1988), Boomer (1988 et seq.), Lord (1988), Arias \& Comas-Rengifo (1992), Arias et al. (1992) and Harloff (1993).

The Zambujal section is situated approximately $15 \mathrm{~km}$ southsouthwest of Coimbra in west-central Portugal, on the flanks of the Maria Pares Hill $\left(48^{\circ} 2^{\prime} \mathrm{N}, 8^{\circ} 28^{\prime} \mathrm{W}\right)$ which overlooks the village of Zambujal (Fig. 1). The section extends along the road from Zambujal to Furadouro and covers the stratigraphical interval between the lowest Pliensbachian through to the top of the Toarcian.

\section{SAMPLING}

A total of 32 outcrop samples were collected during June 1973 by K. Hooper and W. Cox, from beds which had been numbered and described by Mouterde et al. (1964). Additional samples from the lower part of the tenuicostatum Zone (semicelatum Subzone) at Zambujal, Peniche, and Brenha have also been examined in order to detail the extinction of the metacopid Ostracoda. The ammonite zonation scheme, bed number, approximate thicknesses, and sample numbers are illustrated in Fig. 2. All of the samples excluding sample 117, which comprised a well indurated marl and could not be broken down, comprised marls or calcareous shales. Several preparation methods were tried (boiling, white spirit, hydrogen peroxide), with the latter proving the best method for breaking down the calcareous sediments. A dry weight of $100 \mathrm{~g}$ per sample was found to be the minimum weight needed to gain representative fossil assemblages (Exton, 1979).

\section{GEOLOGY AND GEOLOGICAL SETTING}

Portugal's Lower Jurassic sediments outcrop in two main regions; firstly in the Lusitanian Basin which is situated to the west of the Hesperian Massif, between $38^{\circ} 30^{\prime} \mathrm{N}$ and $41^{\circ} \mathrm{N}$, and secondly in an east-west strip on the southern flank of the Algarve Massif. The Lower Jurassic sediments of the Zambujal section are situated close to the present day eastern margin of the Lusitanian Basin, close to the Hesperian Massif (Fig. 1). Throughout the Lusitanian Basin, the Lower Jurassic sediments are dominated by dolomites, limestones and marls, attaining a maximum thickness of over $600 \mathrm{~m}$ in the northwest of the region (Figueira da Foz).

The earliest Jurassic sediments in the Lusitanian Basin belong to the Hettangian Dagorda Formation, comprising greyish red marls with dolomites and evaporites (Fig. 3). This formation marks the initial marine transgression upon the terrestrial red lithologies of the Upper Triassic Silves Formation. The overlying Coimbra Formation consists of dolomites and dolomitic limestones and marks the onset of shallow marine conditions throughout the Lusitanian Basin. The upper boundary of this formation is highly diachronous, ranging in age from Upper Sinemurian (obtusum Zone) in northwestern outcrops (e.g. Sao Pedro de Muel) close to the basin axis, to Lower Pliensbachian (jamesoni Zone) in southeastern outcrops (e.g. Tomar) close to the original basin margin (Mouterde et al., 1971). The interbedded shales, marls and limestones of the overlying informally named Brenha Formation constitute the remainder of the Lower Jurassic succession. The relative proportion of limestones to marl/shale within this formation varies according to the proximity to the paleomargin of the basin. In the vicinity of Tomar, towards the southeastern margin, the marls and shales do not form a significant component of the sediments until the Lower Toarcian. Predominantly argillaceous sedimentation commenced in the Upper Sinemurian towards the basin centre (e.g. Sao Pedro de Muel). A gradual increase in basin 


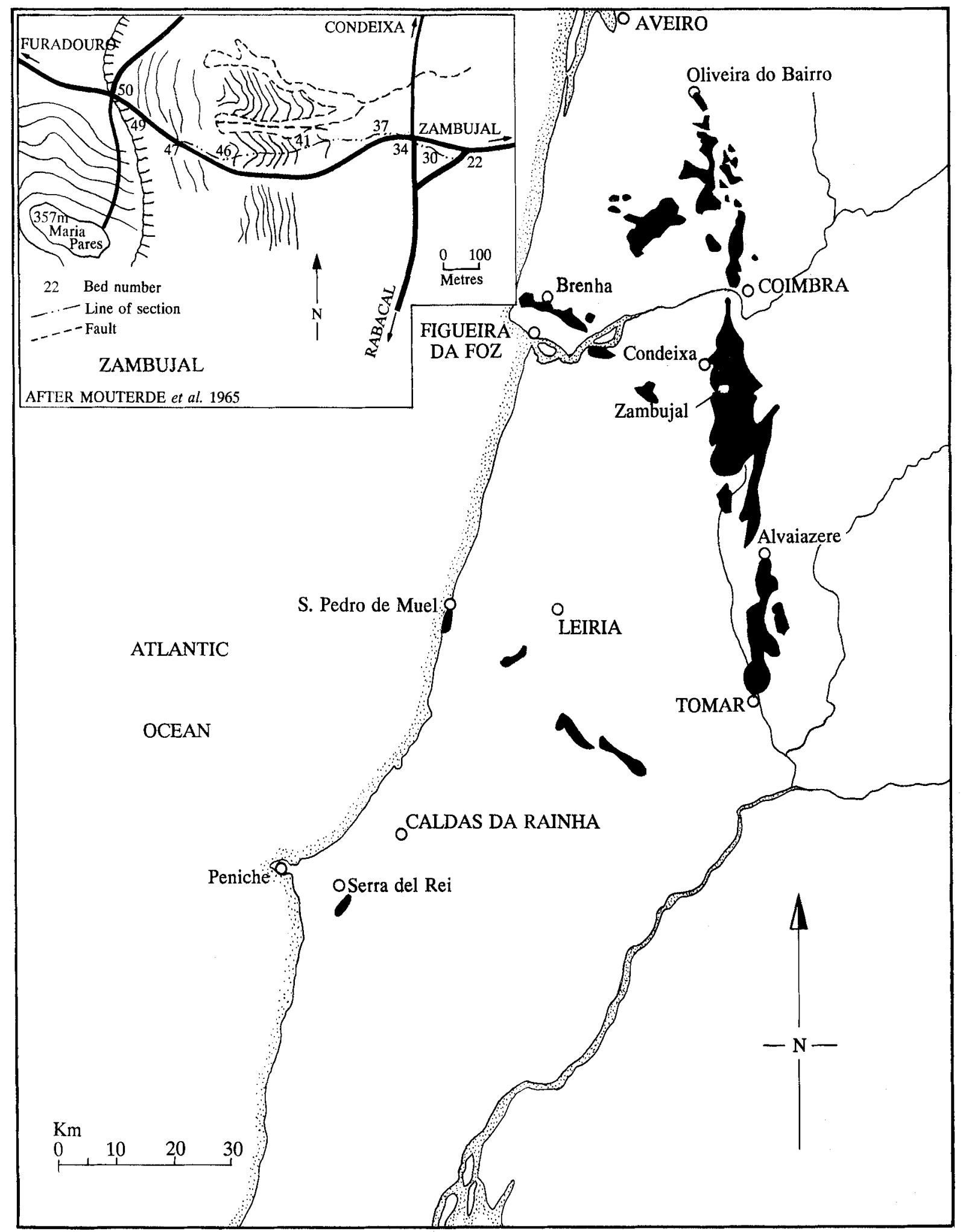

Fig. 1. Location of Lower Jurassic outcrops in west central Portugal. 


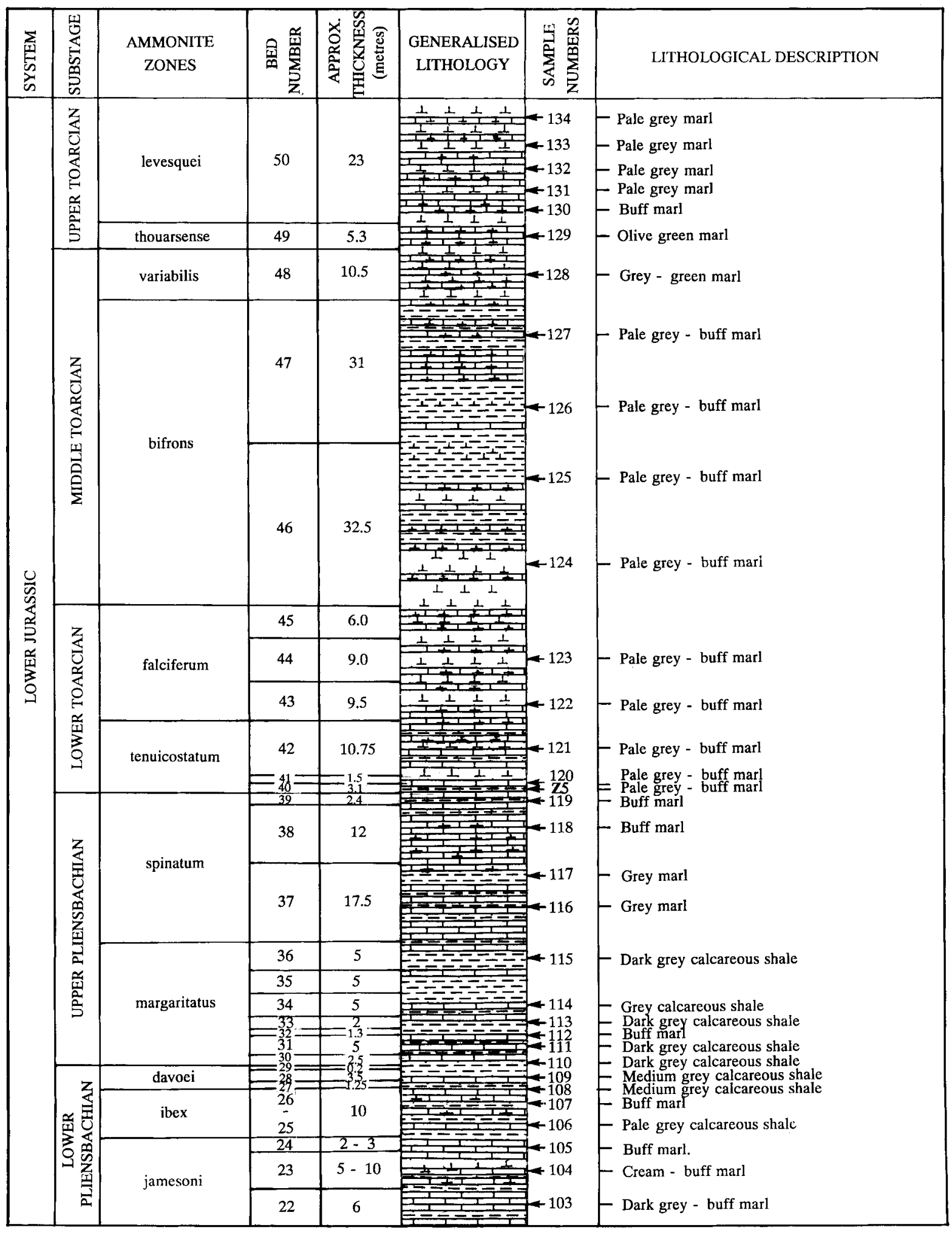

Fig. 2. Stratigraphic summary of the Zambujal section. 


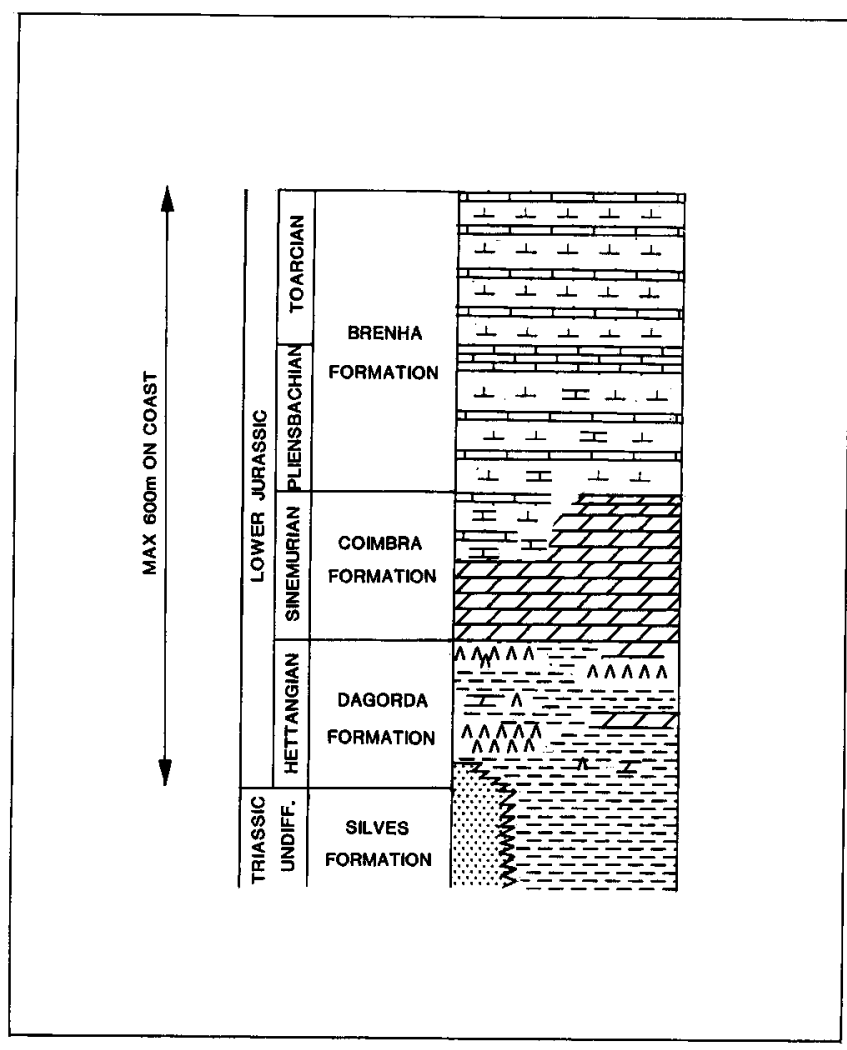

Fig. 3. A generalized lithostratigraphy of the Lusitanian Basin.

water depth occurred throughout the Sinemurian and Lower Pliensbachian, with an apparent maximum water depth occurring in the margaritatus Zone of the Upper Pliensbachian. This corresponds to the most widespread episode of argillaceous sedimentation, and also to the common occurrence of bituminous shale beds in the central part of the basin (e.g. Sao Pedro de Muel and Peniche). These 'deep' water shales are abruptly overlain throughout the basin by limestones and indurated marls of the spinatum Zone. The position of the PliensbachianToarcian boundary within the Portuguese succession is not well defined. The well indurated limestone and marl sequence containing spinatum Zone ammonites forms an easily recognizable lithostratigraphic unit throughout the Lusitanian Basin. A combination of lithostratigraphic and biostratigraphic criteria has apparently been used to place the boundary at the point where these hard lithologies are abruptly overlain by soft bluegrey shales containing abundant specimens of pyritized juvenile dactylioceratid ammonites. However, from the faunal lists provided by Mouterde (1955) for the Peniche coastal exposures, it would appear that a more acceptable boundary position is at the base of Mouterde's Bed 15e, within the limestone-marl unit, corresponding to the first appearance of Paltarpites paltus (K. Page, pers. comm., 1994). The underlying beds contain ammonites of the genus Tauromeniceras belonging to the emaciaticeras Zonule (K. Page, in press) which is believed to be equivalent in age to the upper part of the spinatum Zone, hawskerense Subzone in northern Europe. The occurrence of soft blue-grey shales with dactylioceratid ammonites immedi- ately above the hard limestone-marl unit has been found in exposures as far apart as Peniche, Brenha and Zambujal. These assemblages are believed to occur within the lower part of the semicelatum Subzone of the tenuicostatum Zone. Sample was collected from these beds approximately $50 \mathrm{~cm}$ to $1 \mathrm{~m}$ above the top of the hard limestone-marl unit. At Zambujal the faunal lists of Mouterde et al. (1964) provide no firm indication of the presence of the paltum Subzone and it is probable that in the basin margin locations a condensed sequence or a discontinuity occurs between the spinatum Zone and the semicelatum Subzone of the Lower Toarcian. The Toarcian succession predominantly consists of marls and shales up to the bifrons Zone; thereafter the frequency and thickness of interbedded limestones gradually increases.

In the Zambujal region, the Pliensbachian and Toarcian comprises a series of calcareous shales, marls and limestones representing the informally named Brenha Formation. The jamesoni-ibex Zones are dominated by interbedded buff to pale grey marls and limestones, with subordinate calcareous shales and claystones. The davoei and margaritatus Zone sediments become progressively more shaley and darker in colour. A marked lithological change can be seen at the top of the margaritatus Zone and into the spinatum Zone, with the occurrence of interbedded hard limestones and grey to buff coloured indurated marls. Within the lower part of the tenuicostatum Zone, an abrupt change in sedimentation witnesses the reappearance of dominantly pale grey to buff calcareous shales and marls, with subordinate limestone development. The interbedded nature of the shale-marl-limestone lithologies continues through the Toarcian and into the Aalenian, although the proportion of limestone to marl and calcareous shale increases, from the bifrons Zone upwards.

\section{OSTRACOD BIOZONATION}

Five ostracod zones are defined for the Pliensbachian and Toarcian of Zambujal, Portugal. All five ostracod zones comprise assemblage zones, using the most abundant ostracod taxa, particularly those which possess limited stratigraphical ranges. The proposed zonation is outlined in Fig. 4, in relation to the ammonite biostratigraphy. Accessory species are also included, where they are considered important within the assemblage. A complete ostracod range chart for the Pliensbachian and Toarcian of Zambujal is presented in Fig. 5.

Gammacythere ubiquita-Ogmoconchella gruendeli Ostracod Zone Definition. Base of the section to the last appearance of Ogmoconchella gruendeli Malz, 1971.

Range. Lower Pliensbachian, jamesoni-ibex Zones (samples 103-107).

Remarks. Both Gammacythere ubiquita Malz \& Lord and Ogmoconchella gruendeli Malz are extremely common within this Zone. Common accessory species include Polycope cerasia Blake, P. cincinnata Apostolescu and Ogmoconcha contractula Triebel. Gammacythere ubiquita Malz \& Lord, Pseudomacrocypris subtriangularis Michelsen and Monoceratina multistriata Michelsen, are also limited to this ostracod assemblage zone.

Polycope cerasia-P. cincinnata Ostracod Zone

Definition. Base of zone defined on the last appearance of 


\begin{tabular}{|c|c|c|c|c|}
\hline 峞 & 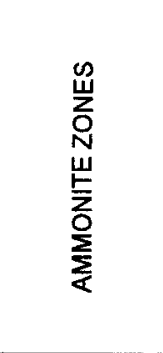 & 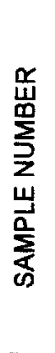 & 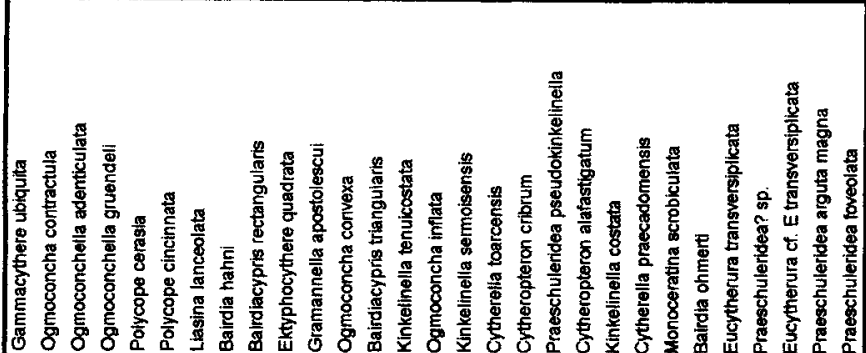 & 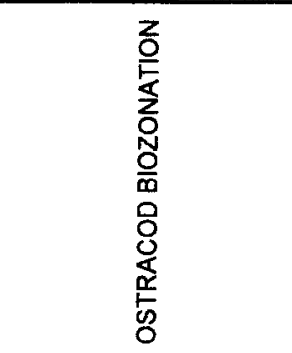 \\
\hline \multirow{8}{*}{$\begin{array}{l}z \\
\alpha \\
- \\
0 \\
\alpha \\
\alpha \\
0 \\
-\end{array}$} & LEVESQUEI & $\begin{array}{l}134 \\
133 \\
132 \\
131 \\
130 \\
\end{array}$ & $\begin{array}{|llllllllll|}1 & & 1 & 1 & 1 & 1 & 1 & 11 \\
& & 1 & 1 & 1 & 1 & 1 & 1 \\
& & & 1 & 1 & 1 & 1 & 1 & 1 \\
& & & 1 & 1 & 1 & 1 & 1 & \\
& 1 & & 1 & 1 & 1 & 1 & 1 & 1 \\
\end{array}$ & \multirow{4}{*}{$\begin{array}{l}\text { C. toarcensis - } \\
\text { K. costata }\end{array}$} \\
\hline & THOUARSENSE & 129 & 11111 & \\
\hline & VARIABILIS & 128 & \begin{tabular}{l|l|l}
1 & 1 & 11 \\
\end{tabular} & \\
\hline & \multirow[b]{2}{*}{ BiFRONS } & $\overline{127}$ & $\begin{array}{lllll}1 & 1 & 1 & 1 & 1\end{array}$ & \\
\hline & & $\begin{array}{l}128 \\
125 \\
124\end{array}$ & $\begin{array}{llll}1 & 1 & & 1 \\
1 & 1 & 1 & 1\end{array}$ & \multirow{3}{*}{$\begin{array}{l}\text { B. rectangularis - } \\
\text { K. sermoisensis }\end{array}$} \\
\hline & FALCIFERUM & $\begin{array}{l}123 \\
122\end{array}$ & $\begin{array}{lll}1 & 1 & 1\end{array}$ & \\
\hline & \multirow[t]{2}{*}{ TENUICOSTATUM } & $\begin{array}{l}121 \\
120\end{array}$ & 1 & \\
\hline & & 25 & 111 & \multirow[b]{2}{*}{$\begin{array}{l}\text { L. lanceolata - } \\
\text { O. convexa }\end{array}$} \\
\hline \multirow{5}{*}{$\begin{array}{l}z \\
\alpha \\
- \\
x \\
0 \\
\alpha \\
\infty \\
\infty \\
z \\
w \\
- \\
- \\
a\end{array}$} & SPINATUM & $\begin{array}{l}119 \\
118 \\
116 \\
\end{array}$ & 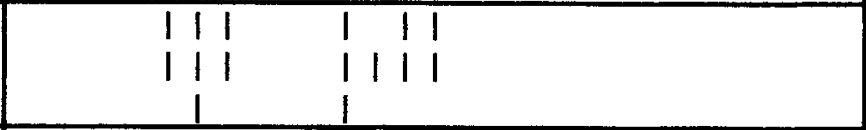 & \\
\hline & MARGARTATUS & \begin{tabular}{l|}
115 \\
113 \\
112 \\
111 \\
110 \\
\end{tabular} & $\begin{array}{ll}1 & 1 \\
1 & 1 \\
1 & 1 \\
1 & 1 \\
11 & 1\end{array}$ & \multirow[t]{2}{*}{$\begin{array}{l}\text { P. cerasia - } \\
\text { P. cincinnata }\end{array}$} \\
\hline & DAVOEI & $\begin{array}{l}109 \\
108\end{array}$ & $\begin{array}{llll} & 11 & 11 \\
11 & 1 & \\
\end{array}$ & \\
\hline & IBEX & & $\begin{array}{lllllll} & 1 & 1 & 1 & 1 \\
1 & 1 & 1 & 1 & 1 & 1 & \\
\end{array}$ & \multirow{2}{*}{$\begin{array}{l}\text { G. ubiquita - } \\
\text { O. gruendeli }\end{array}$} \\
\hline & JAMESONI & $\begin{array}{l}105 \\
104 \\
103\end{array}$ & $\begin{array}{llllllll}1 & & 1 & 1 & & 1 \\
1 & 1 & 1 & 1 & 1 & 1 & 1 \\
1 & & & & & \end{array}$ & \\
\hline
\end{tabular}

Fig. 4. Ostracod biozonation scheme of the Zambujal section.

Ogmoconchella gruendeli Malz, with top of the zone marked by the first appearance of Ogmoconcha convexa Boomer.

Range. Uppermost Lower-lowermost Upper Pliensbachian, davoei-margaritatus Zones (samples 108-115).

Remarks. Throughout this interval, species of Polycope dominate the assemblage, reaching a peak abundance of over $90 \%$ in sample 111 (lower margaritatus Zone) (Fig. 5). The Metacopina are absent from many of the samples within this assemblage zone. Monoceratina amlingstadtensis Triebel \& Bartenstein, Monoceratina michelseni Riegraf, Eucytherura zambujalensis sp. nov., Ogmoconcha contractula Triebel, Ogmoconchella adenticulata (Pietrzenuk) and Paracypris redcarensis (Blake) have their last occurrences within this zone. Ektyphocythere quadrata Boomer \& Lord, Gramannella apostolescui (Gramann) and Paradoxostoma pusillum Michelsen are restricted to this zone.

\section{Liasina lanceolata-Ogmoconcha convexa Ostracod Zone}

Definition. Base of zone defined on the common occurrence of Liasina lanceolata (Apostolescu), in association with the first appearance of Ogmoconcha convexa Boomer. The top of the 


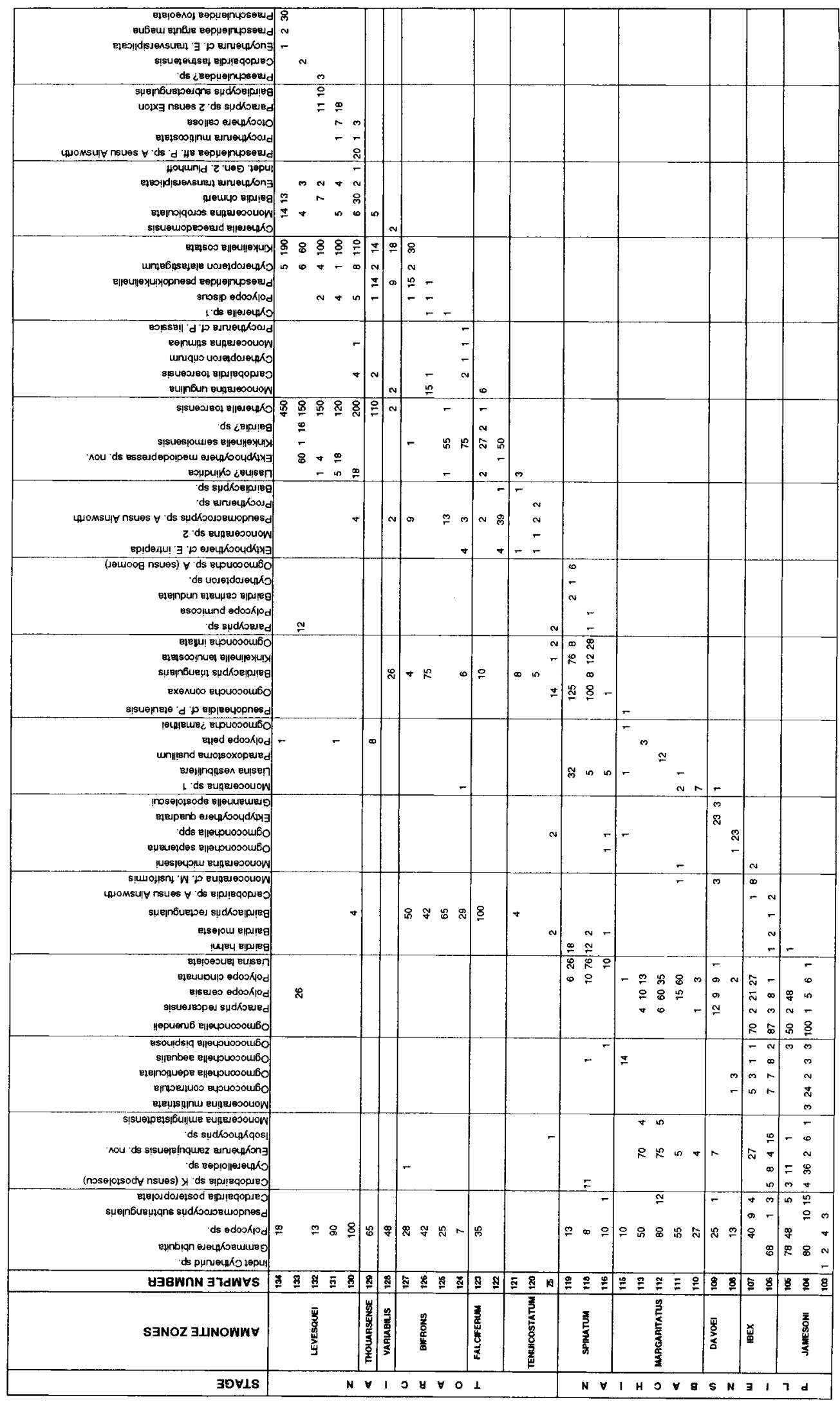


zone is defined by the first appearance of Bairdiacypris rectangularis Ainsworth.

Range. Uppermost Pliensbachian-lowermost Toarcian, spinatum-lower tenuicostatum Zones (samples 116-119, Z5).

Remarks. Both index taxa are extremely common within this interval. Species which have their last occurrences within the zone include Polycope cincinnata Apostolescu, Liasina lanceolata (Apostolescu), L. vestibulifera Gramann, Bairdia hahni Lord \& Moorley, Ogmoconchella aequalis Herrig and $O$. septenaria (Gründel). Ogmoconcha convexa Boomer, O. inflata (Ainsworth), $O$. sp. A sensu Boomer, 1992, Kinkelinella tenuicostata Martin and Bairdia carinata undulata Herrig are restricted to this zone.

The Upper Pliensbachian-lowermost Toarcian ostracod assemblages recorded at Zambujal show strong similarities with those of the Early Toarcian (essentially tenuicostatum Zone) of northern Europe (Boomer \& Ainsworth, in press). Throughout much of Europe, the Metacopina become extinct within the tenuicostatum Zone. However, in the Mochras Borehole, North Wales, their extinction occurs in the lowermost falciferum Zone (Boomer, 1991).

\section{Bairdiacypris rectangularis-Kinkelinella sermoisensis Ostracod Zone}

Definition. Base of zone defined on the first occurrence of Bairdiacypris rectangularis Ainsworth and/or Kinkelinella sermoisensis (Apostolescu), with the top of the zone defined by the first appearance of Kinkelinella costata Knitter, in association with large numbers of Cytherella toarcensis Bizon.

Range. Lower Toarcian-lowermost Middle Toarcian, upper tenuicostatum-upper bifrons Zones (samples 120-126).

Remarks. This assemblage is initially marked by low diversity and low abundance ostracod assemblages (samples 120, 121) (Fig. 5), similar in composition to those described by Ainsworth (1986) and Boomer (1991) from contemporary sequences in the Fastnet Basin and the Mochras Borehole, respectively. These assemblages directly follow the extinction of the Metacopina.

The Bairdiacypris rectangularis-Kinkelinella sermoisensis Zone contains part of Exton \& Gradstein's (1984) Bairdiacypris sp. Assemblage Zone. That Zone ranged from mid. tenuicostatum to the top of the variabilis Zone, and was based on the abundant occurrence of an unnamed species of Bairdiacypris sp. recorded by Bate \& Coleman. Ektyphocythere aff. E. intrepida Bate \& Coleman, is the only taxon to be stratigraphically restricted to this Zone. Common accessory species include Bairdiacypris triangularis Ainsworth and Polycope sp.

\section{Cytherella toarcensis-Kinkelinella costata Ostracod Zone}

Definition. Base of zone defined on the first appearance of Kinkelinella costata Knitter, in association with large numbers of Cytherella toarcensis Bizon.

Range. Uppermost Middle--Upper Toarcian, uppermost bifronsupper levesquei Zones (samples 127-134).

Remarks. From the base of the thouarsense Zone (Upper Toarcian) upwards, the assemblages are dominated by the Platycopina, mainly Cytherella toarcensis Bizon (Fig. 5). Accessory species within this zone include Cytheropteron alafastigatum Fischer, Monoceratina scrobiculata Triebel \& Bartenstein, Bairdia ohmerti Knitter, Eucytherura transversipli- cata (Bate \& Coleman), Praeschuleridea arguta magna Ainsworth and $P$. foveolata Ainsworth. The occurrence of Praeschuleridea pseudokinkelinella Bate \& Coleman, in Zambujal (upper bifrons-thouarsense Zones) is stratigraphically higher than those occurrences in northern Europe, where it ranges from the falciferum through to lower variabilis Zones.

\section{OSTRACOD BIOSTRATIGRAPHY OF THE ZAMBUJAL SECTION}

Eighty species of Ostracoda have been recognized from the Pliensbachian and Toarcian of Zambujal, Portugal by the present authors (Fig. 5). The marked increase in faunal diversity compared to the earlier study by Exton (1979) reflects the numerous studies undertaken on European Lias sequences since 1979. Many of the taxa from Zambujal have been described throughout northern Europe, albeit with discontinuous or differing stratigraphic ranges, reflecting either the geographical setting and/or facies variation.

\section{Lower Pliensbachian}

Thirty ostracod species occur in the Lower Pliensbachian of Zambujal (Fig. 4). Notable occurrences include Gammacythere ubiquita Malz \& Lord, Gramannella apostolescui (Gramann), Ektyphocythere quadrata Boomer \& Lord, Monoceratina multistriata Michelsen, Cardobairdia sp. A sensu Ainsworth, Ogmoconcha contractula Triebel, Ogmoconchella adenticulata (Pietrzenuk), O. gruendeli Malz, Cardobairdia posteroprolata Ainsworth, C. sp. K (sensu Apostolescu), Polycope cerasia Blake, P. cincinnata Apostolescu, Bairdia hahni Lord \& Moorley, B. molesta Apostolescu, Bairdiacypris rectangularis Ainsworth, Paracypris redcarensis (Blake), Liasina lanceolata (Apostolescu), Monoceratina michelseni Riegraf, $M$. amlingstadtensis Triebel \& Bartenstein, Eucytherura zambujalensis sp. nov., Ogmoconchella aequalis Herrig, $O$. bispinosa (Gründel) and $O$. septenaria (Gründel). The first nine taxa are stratigraphically restricted to the Lower Pliensbachian. Ten species become locally extinct by the end of the Early Pliensbachian (Fig. 5).

Throughout this interval, the assemblages are generally represented by three groups, the Cladocopina (Polycope cerasia Blake, P. cincinnata Apostolescu), the Metacopina (Ogmoconcha contractula Triebel, Ogmoconchella gruendeli Malz) and the cytheracean species (Gammacythere ubiquita Malz \& Lord, Eucytherura zambujalensis sp. nov.).

\section{Upper Pliensbachian}

Thirty-one species of Ostracoda occur in the Upper Pliensbachian, of which 14 have their originations. Notable first appearances include Liasina vestibulifera Gramann, Paradoxostoma pusillum Michelsen, Kinkelinella tenuicostata Martin, Ogmoconcha inflata (Ainsworth), O. convexa Boomer and $O$. sp. A sensu Boomer. Of the 31 taxa occurring in the Upper Pliensbachian, eight are stratigraphically restricted, while 21 species become locally extinct by the end of the Upper Pliensbachian interval (Fig. 5).

In the margaritatus Zone (samples $110-115$ ), the ostracod assemblages are dominated by the Cladocopina (Polycope cerasia Blake, $P$. cincinnata Apostolescu), in association with Eucytherura zambujalensis sp. nov. Both the Metacopina (absent in samples 110-113) and cytheracean components of the 
assemblage are less abundant than in the preceding Zone (Fig. 5). A marked faunal change occurs in the spinatum Zone (samples 116-119), with the assemblage dominated by the Metacopina (Ogmoconcha convexa Boomer, O. inflata (Ainsworth)), in association with Kinkelinella tenuicostata Martin and Liasina vestibulifera Gramann. Three Ogmoconcha species occur in the spinatum Zone. Ogmoconcha inflata (Ainsworth) and possibly $O$. sp. A sensu Boomer can be considered as 'vallate forms' which, although first described from Pliensbachian 'Tethyan' deposits from southern Germany (Malz, 1975), have subsequently been described throughout much of Europe and North Africa (Ainsworth, 1987; Boomer, 1992). The other species of Ogmoconcha recorded from the Upper Pliensbachianlowermost Toarcian of Zambujal, $O$. convexa Boomer, has also been recorded from the spinatum-tenuicostatum Zones of southern England, the Mochras Borehole, Wales and offshore southwest Ireland (Boomer, 1991, 1992; Ainsworth et al., 1989).

\section{Lower Toarcian}

Twenty species of Ostracoda are present in the Lower Toarcian of Zambujal of which 11 taxa have their first appearances. Newly occurring taxa include Cytherella toarcensis Bizon, Pseudomacrocypris sp. A sensu Ainsworth, Liasina? cylindrica Ainsworth, Monoceratina ungulina Triebel \& Bartenstein, Ektyphocythere cf. E. intrepida Bate \& Coleman, E. mediodepressa sp. nov. and Kinkelinella sermoisensis (Apostolescu). All the above seven taxa range into the Middle Toarcian (Fig. 5). Eight species become locally extinct by the end of the Lower Toarcian.

A marked change in the ostracod assemblage occurs within the lower part of the tenuicostatum Zone (sample Z5), with the extinction of the Metacopina, in association with an abrupt decline in faunal diversity and abundance. During the upper part of the tenuicostatum Zone (samples 120, 121), a slight increase in faunal diversity and abundance is noted (Fig. 5). This marked faunal turnover occurs throughout much of onshore and offshore northwest Europe during this time.

A further increase in diversity and abundance occurs within the falciferum Zone (samples 122, 123), with 12 species present. The assemblages are dominated by Bairdiacypris ( $B$. triangularis Ainsworth, B. rectangularis Ainsworth), Pseudomacrocypris sp. A sensu Ainsworth and Kinkelinella sermoisensis (Apostolescu). Similar assemblages have been described from the Fastnet and North Celtic Sea Basins (Ainsworth, 1986; Ainsworth et al., 1989).

\section{Middle Toarcian}

Twenty-one species of Ostracoda occur in the Middle Toarcian of which 10 have their originations. Notable first appearances include Polycope discus Fischer, Cardobairdia toarcensis Ainsworth, Cytheropteron alafastigatum Fischer, Kinkelinella costata Knitter and Praeschuleridea pseudokinkelinella Bate \& Coleman. All five taxa range into the Upper Toarcian. Overall the assemblages are dominated by Polycope sp., Bairdiacypris (B. rectangularis Ainsworth, $B$. triangularis Ainsworth), Kinkelinella sermoisensis (Apostolescu) in samples 124 and 125, and $K$. costata Knitter, in samples 127 and 128 and Praeschuleridea pseudokinkelinella Bate \& Coleman. By the end of the Middle Toarcian, nine taxa have become extinct (Fig. 5). Many of these taxa are common throughout northern Europe during this time.

\section{Upper Toarcian}

Thirty-one species of Ostracoda have been recovered from the Upper Toarcian of Zambujal, of which 14 taxa have their originations (Fig. 5). First appearances include Bairdia ohmerti Knitter, Monoceratina scrobiculata (Triebel \& Bartenstein), Eucytherura transversiplicata (Bate \& Coleman), Otocythere callosa Triebel \& Klingler, Praeschuleridea arguta magna Ainsworth, $P$. foveolata Ainsworth and Praeschuleridea aff. $P$. sp. A sensu Ainsworth.

Throughout this interval, the assemblages are dominated by Polycope sp., Cytherella toarcensis Bizon, Bairdia ohmerti Knitter, Ektyphocythere mediodepressa sp. nov., Kinkelinella costata Knitter, and to a lesser extent by Praeschuleridea ( $P$. foveolata Ainsworth, $P$. aff. $P$. sp. A sensu Ainsworth), and Monoceratina scrobiculata Triebel \& Bartenstein.

The thouarsense Zone (sample 129) assemblage is very similar in composition to the underlying variabilis Zone. A marked increase in faunal diversity and abundance occurs at the base of the levesquei Zone (sample 130), with the occurrence of six new species (Fig. 5). Many of the taxa have been described from northwest Europe, especially in those studies of Ainsworth (1986) and Boomer (1991) from the Toarcian and Aalenian of the Fastnet Basin and Mochras Borehole, respectively. Praeschuleridea pseudokinkelinella Bate \& Coleman is noteworthy for its higher stratigraphical range (upper bifronsthouarsense Zone) at Zambujal, compared with that in England (falciferum-bifrons Zones).

\section{FAUNAL ANALYSIS}

Changes in the faunal composition of the Ostracoda at the suborder-superfamily level in the Zambujal sequence are numerically illustrated in Fig. 6. From these data, a number of distinct 'episodes' with characteristic assemblages are noted, at least one of which is of global significance. To interpret these changes in faunal composition it is also necessary to integrate information both on diversity levels and rates of faunal turnover, as outlined in Fig. 7. It must be noted beforehand that the sampling strategy was strongly influenced by the sediment type (e.g. only marls and calcareous shales were processed). Futhermore, none of the data take into account the weight of the unprocessed sample.

The earliest sediments studied (jamesoni to davoei Zones, samples 103-109) yield quite diverse assemblages dominated by the Cytheracea and the Metacopina. During most of the succeeding margaritatus Zone interval, however, there are no Metacopina recorded. These assemblages are dominated (up to $90 \%$ ) by the Cladocopina (as species of Polycope). This undoubtedly reflects some environmental shift at the site of deposition. Not only are the Cladocopina the most abundant faunal group as a percentage of the samples during this interval, but they are also numerically abundant in absolute terms.

No modern analogue is known for such assemblages. The Cladocopina occur in almost all marine environments, however, they are rarely encountered in large numbers ( $R$. C. Whatley, pers comm.). Diverse cladocopine assemblages have been recorded from the Quaternary of the Arctic Ocean (Joy \& Clark, 1974). Lower Jurassic assemblages from other European 

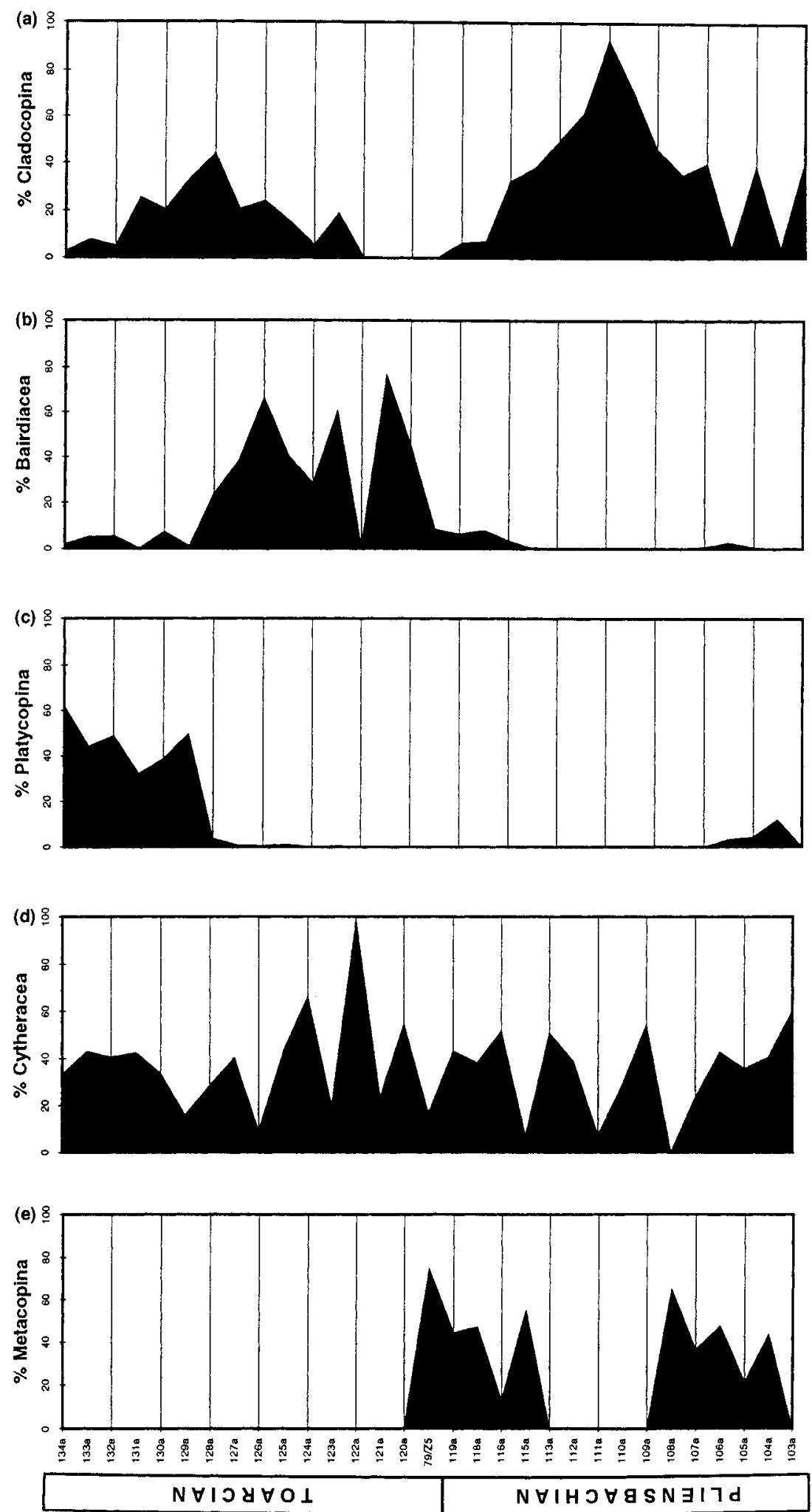

Fig. 6. The faunal composition is represented by the percentage of (a) Cladocopina, (b) Bairdiacea, (c) Platycopina, (d) Cytheracea and (e) Metacopina throughout the sequence. For detailed stratigraphy see the text and Fig. 2. 
(a)

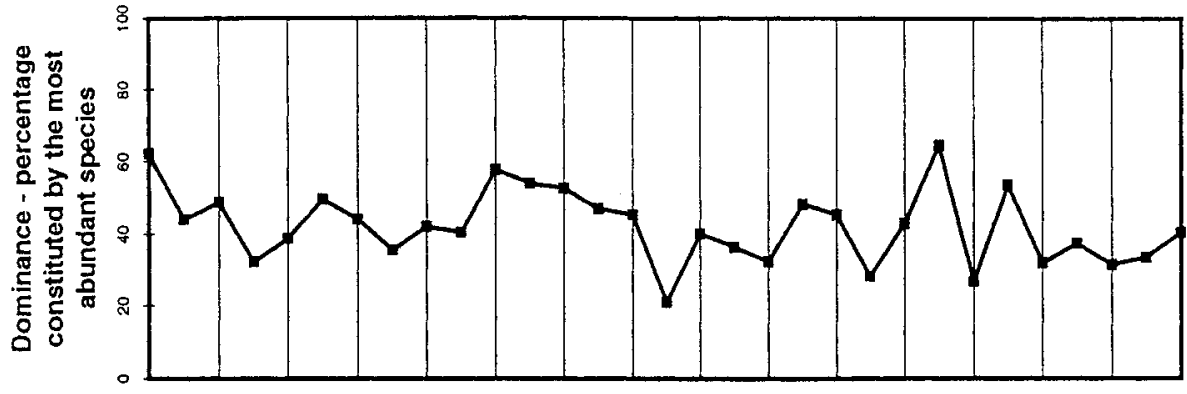

(b)

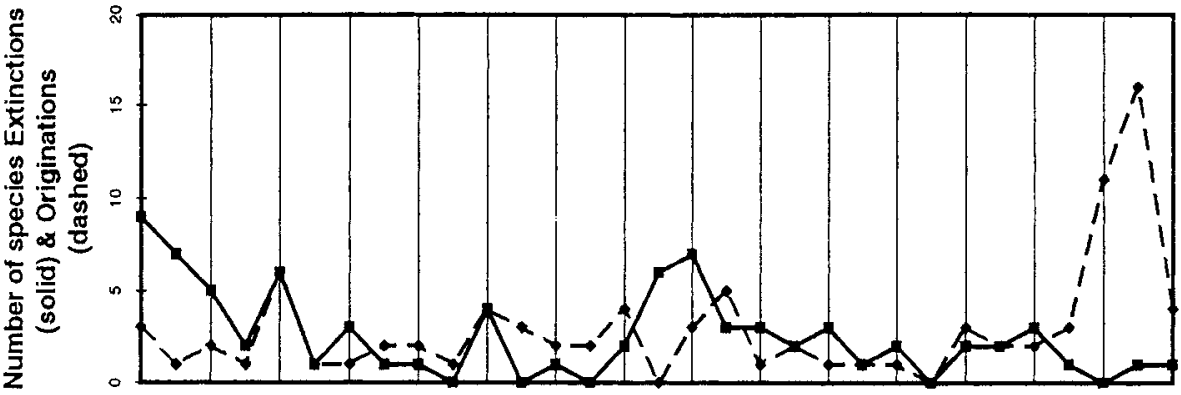

(c)

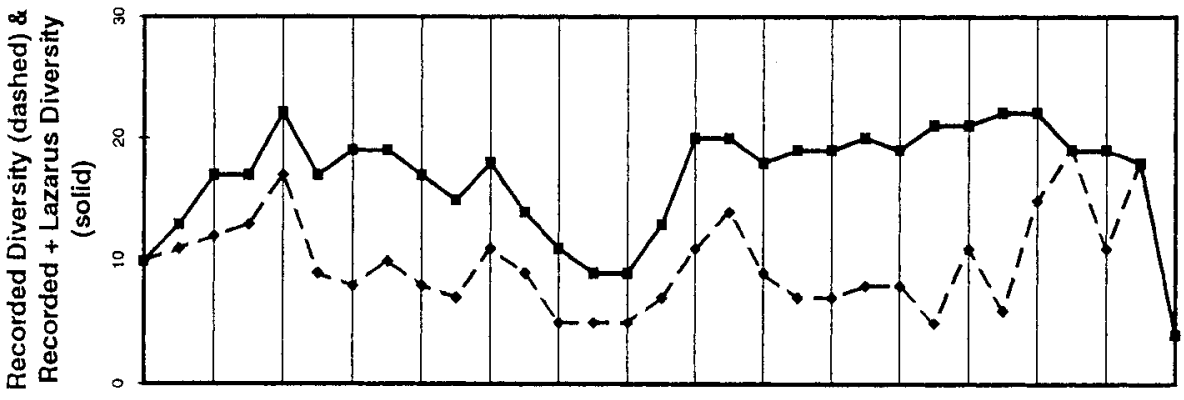

(d)

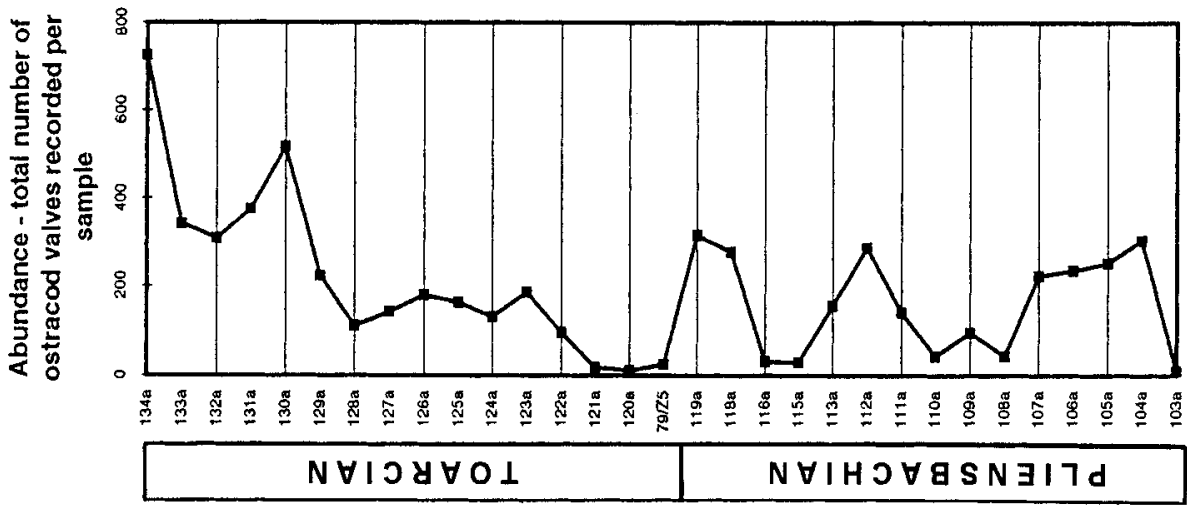

Fig. 7. Changes in the ostracod assemblages are recorded in four ways. (a) Dominance, this is calculated as the percentage, for a given sample, constituted by the single most abundant species. (b) Faunal Turnover, the number of species having their first appearance (Originations) and those with their last appearance (Extinctions) in each sample. (c) Diversity is recorded in two ways. Firstly, as the number of species present in a sample (Recorded Diversity) and secondly, as the recorded diversity plus the number of taxa, termed lazarus species, which are apparently absent but are recorded stratigraphically above and below that sample (Compound Diversity). (d) Specimen Abundance, the number of valves per sample. For detailed stratigraphy see the text and Fig. 2. 
sections commonly record Polycope species, but never in such high numbers or in such dominance.

The peak in Polycope abundance declines steadily from the lower part of the margaritatus Zone (sample 111), with the uppermost margaritatus Zone (sample 115) interval seeing a return to the assemblages recorded in the lowest part of the sequence. These conditions continue through to the top of the spinatum Zone (sample 119). At this junction, specimen abundance sees a marked decrease. This in itself is perhaps not significant since similar fluctuations occur throughout the sequence, however, this decrease is concomitant with the onset of a marked diversity trough (Fig. 7b) and an increased extinction rate (Fig. $7 \mathrm{c}$ ).

This event was described by Exton (1979) as being the point at which the Metacopina became extinct in the Lusitanian Basin and the timing of this event was thought to be consistent throughout much of northwest Europe. Subsequent studies (Boomer, 1991, 1992) have shown that the timing of this extinction event can be traced through to the tenuicostatum and even falciferum zones of the Early Toarcian in some more northerly sequences.

As a result of more detailed sampling of the Zambujal and Peniche sections, in association with careful ammonite biostratigraphical control (K. Page, pers. comm.), we have established that the final extinction of the Metacopina in the Lusitanian Basin must have occurred during the earliest Toarcian (tenuicostatum Zone) and not at the Pliensbachian/ Toarcian boundary.

Whatever events brought about the demise of the Metacopina the conditions were not completely inimical to the survival of benthonic Ostracoda. The abundance remained low, with diversity halved during the tenuicostatum and lower falciferum Zones (samples Z5, 120-122), yet by the beginning of the Middle Toarcian (upper falciferum Zone, sample 123) the assemblages had recovered to their former species richness. From Fig 6, it would appear that the niche left by the Metacopina was filled initially by the Bairdiacea which had hitherto only been rarely recorded in the sequence. The Cladocopina also increase in importance during the Middle Toarcian, but by the Upper Toarcian (thouarense Zone, sample 129) they had begun to decrease and they, together with the Bairdiacea, had been replaced by the Platycopina. The success of the latter group is in accordance with the observations of Boomer (1991) and Boomer $\&$ Whatley (1992) where the demise of the Metacopina in the extensive Liassic sequence of the Mochras Borehole, led to the subsequent success of the Platycopina.

The Middle and Upper Toarcian intervals are known to be characterized by periods of low oxygen conditions throughout much of Northwest Europe with the success of the Platycopina during this time being attributed to their filter feeding mode of life bestowing a greater survival capability in reduced oxygen environments (Whatley, 1991). This is probably a simplification of the Lower Jurassic picture since many non-platycopids also survive these kenoxic periods. It should be noted, however, that no evidence of oxygen deficient conditions have been observed in the Toarcian sedimentary record of Portugal. It is almost incontrovertible that the loss of such an important and long ranging group as the Metacopina, led to a large niche availablity which the Platycopina were best able to take advantage of.
The Upper Toarcian (samples 129-134) sequence appears to show a steadily increasing dominance of Platycopina. In the youngest sample (134) examined, the dominance (fig. $7 \mathrm{~d}$ ) is almost at its greatest in the sequence, diversity is decreasing and abundance increasing. This suggests increasing environmental stress where one group or one species is best adapted to survive and reproduce.

\section{SYSTEMATIC DESCRIPTIONS}

Figured specimens deposited in the collections of the Deparment of Palaeontology, Natural History Museum, London.

Class Ostracoda Latreille, 1806

Order Podocopida Müller, 1894

Suborder Podocopina Sars, 1866

Superfamily Cytheracea Baird, 1850

Family Cytherideidae Sars, 1925

Genus Ektyphocythere Bate, 1963

Ektyphocythere mediodepressa sp. nov.

(Fig. 8, figs 1-8)

1979 Ektyphocythere sp. 2, Exton: 59, pl. 13, figs 1, 2.

Derivation of name. With reference to the vertical depression in the mid-valve region formed by the discontinuation of ribbing. Diagnosis. Carapace of medium size, subtriangular. Ornament of strongly developed open ribbing with few poorly developed cross-ribs. Mid-lateral ribs short and thickened, often discontinuous, forming a vertically aligned depression extending from mid-valve region towards apex of triangular ribbing. The depression is often bounded by vertically aligned elements of ribbing.

Holotype. Adult female RV; Natural History Museum (NHM), London OS 14839.

Material. 80 valves, three carapaces (Paratypes NHM, London OS 14836-OS 14838 and OS 14840-OS 14843).

Locality and horizon. Maria Pares Hill section, Zambujal, $48^{\circ} 2^{\prime} \mathrm{N}, 8^{\circ} 28^{\prime} \mathrm{W}$, sample 133 , Bed 50, levesquei Zone, Upper Toarcian, Lower Jurassic.

Description. Carapace of medium size, subtriangular in lateral view, subovate in dorsal view. Anterior margin asymmetrically rounded, extremity slightly below mid-height. Posterior margin rounded subtriangular in left valves, subtriangular in right valves, extremity below mid-height. Dorsal margin slightly convex to straight in left valves, straight with prominent cardinal angles in right valves. Posterior margin convex, tapering towards posterior. Maximum length below mid-height, maximum height at anterior cardinal angle, maximum width behind mid-length. Left valve larger than right valve, overlapping right valve dorsally and ventrally. Sexually dimorphic, male dimorph more elongate than female. Carapace strongly calcified. Ornament of strongly developed open, longitudinal ribbing with poorly defined cross-ribs forming subrounded to subovate reticulation. Mid-laterally, ribbing short and thickened, often discontinuous, forming a vertically aligned depression, extending from mid-valve region towards apex of triangular ribbing. This depression is bounded by vertically aligned elements of ribbing. Eye spot moderately well developed. Eye sulcus less well defined. Inner lamella moderately broad, line of concresence coincides with inner margin. Radial pore canals not observed. Hinge antimerodont; right valve terminal dentate 


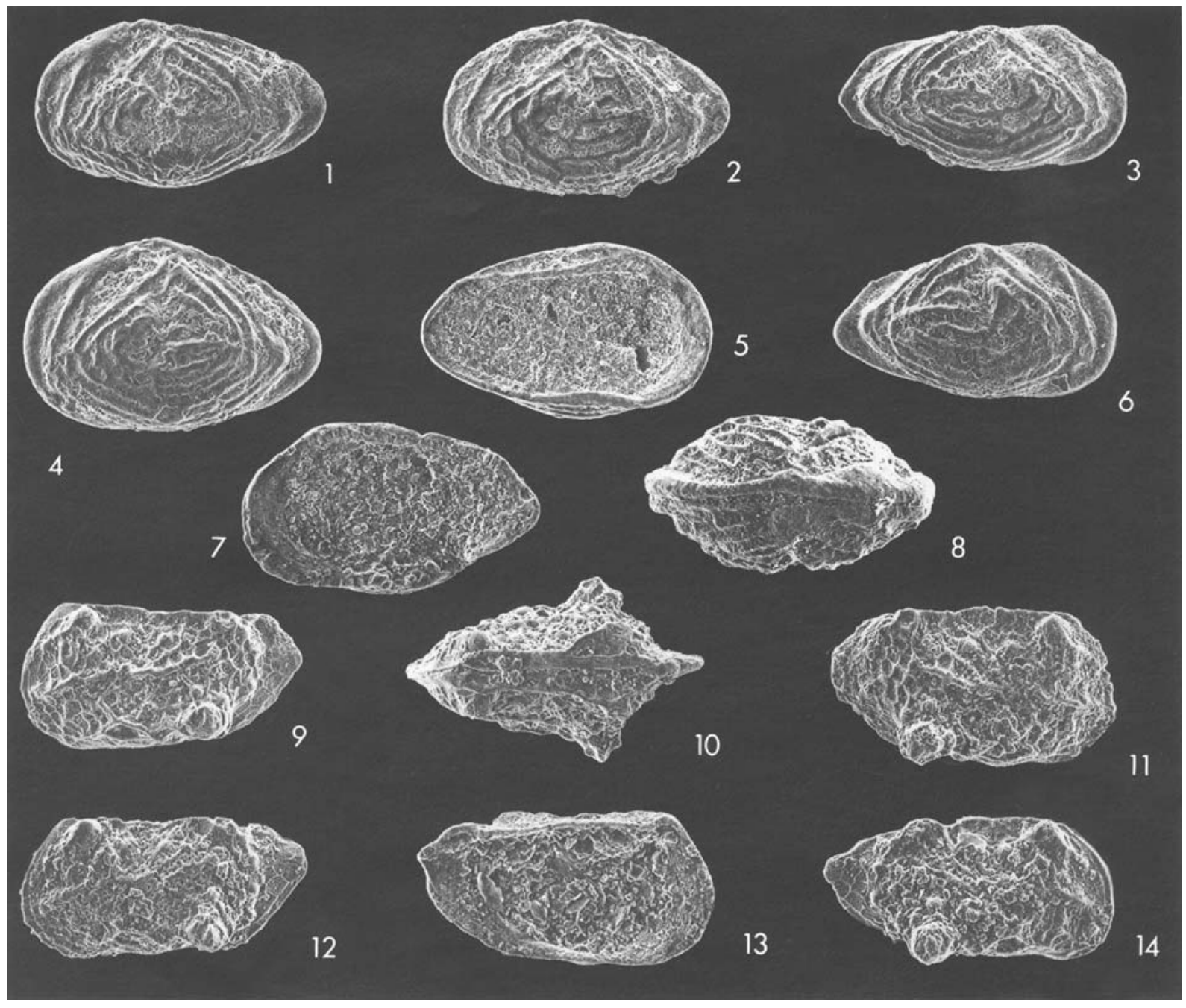

Fig. 8. $\mathrm{F}=$ Female, $\mathrm{M}=$ Male, $\mathrm{LV}=$ Left valve, $\mathrm{RV}=$ Right valve, $\mathrm{CAR}=$ Carapace, all external lateral views unless otherwise stated. All specimens deposited in the collections of the Department of Palaeontology, Natural History Mueum, London. figs 1-8. Ektyphocythere mediodepressa sp. nov., sample 133, Bed 50, levesquei Zone, Upper Toarcian, Lower Jurassic of Zambujal. 1. MLV, $\times 54$, OS 14836, paratype. 2. FLV, $\times 63$, OS 14837, paratype. 3. MRV, $\times 56$, OS 14838, paratype. 4. FLV, $\times 64$, OS 14839, holotype. 5. MLV, internal lateral view, $\times 54$, OS 14840, paratype. 6. FRV, $\times 64$, OS 14841, paratype. 7. FRV, internal lateral view, $\times 66$, OS 14842, paratype. 8. FCAR, dorsal view, $\times 60$, OS 14843, paratype. Figs 9-14. Eucytherura zambujalensis sp.nov., sample 113, Bed 33, margaritatus Zone, Upper Pliensbachian, Lower Jurassic of Zambujal. 9. FLV, $\times 100$, OS 14844, holotype. 10. FCAR, dorsal view, $\times 108$, OS 14845, paratype. 11. FRV, $\times 108$, OS 14846, paratype. 12. MLV, $\times 101$, OS 14847 , paratype. 13 . FLV, internal lateral view, $\times 116$, OS 14848, paratype. 14. MRV, $\times 105$, OS 14849, paratype.

ridges comprising six subovate teeth, separated by a straight, finely locellate groove. Left valve complementary, but with a well-developed wide accommodation groove above median hinge element, which thins towards posterior-loculate socket. Muscle scar pattern not observed.

Dimensions. Length $600-740 \mathrm{~mm}$, height $360-400 \mu \mathrm{m}$.

Distribution. At present, only recorded from the type locality, sample 122, bed 43, falciferum Zone, Lower Toarcian, samples 131-133, bed 50, levesquei Zone, Upper Toarcian.

Remarks. This species shows similarities to both Ektyphocythere intrepida Bate \& Coleman, 1975 and E. ambo Boomer, 1992. It can be distinguished from both these species by the discontinuous median ribbing and the occurrence of a central vertically aligned depression.
Family Cytheruridae Müller, 1894

Genus Eucytherura Müller, 1894

Eucytherura zambujalensis sp. nov.

(Fig. 8, figs 9-14)

1979 ? Cytheropteron sp. Exton: 57, p1. 9, figs 1, 3.

Derivation of name. With reference to the occurrence of this species from the type locality of Zambujal.

Diagnosis. Carapace very small, subtriangular, strongly inflated laterally. Ornament of ribbing and reticulation similar to that of Eucytherura transversiplicata, Bate \& Coleman, 1975 but with very prominent postero-ventral and postero-dorsal nodes and eye nodes. Well formed dorsal flange in right valve.

Holotype. Adult female LV; Natural History Museum, London OS 14844. 
Material. 189 valves, five carapaces (Paratypes NHM, London OS 14845-OS 14849).

Locality and horizon. Maria Pares Hill section, Zambujal, $48^{\circ} 2^{\prime} \mathrm{N}, 8^{\circ} 28^{\prime} \mathrm{W}$, sample 113 , Bed 33 , margaritatus Zone, Upper Pliensbachian, Lower Jurassic.

Description. Carapace very small, subtriangular in lateral view, inflated in dorsal view. Anterior margin slightly asymmetrically rounded, extremity immediately below mid-height. Posterior margin subtriangular, extremity above mid-height. Dorsal margin slightly sinuous. Posterior margin weakly convex, tapering upwards towards posterior margin. Maximum length above mid-height, maximum height at anterior cardinal angle, maximum width behind mid-length at posterior termination of postero-ventral nodes. Left valve slightly larger than right. Carapace moderately strongly calcified. Ornament of moderately coarse polygonal reticulation, most strongly developed centrally, weakening towards the margins. Three oblique ribs developed anteriorly, the uppermost rib joins onto a welldeveloped eye node, the central rib extends from below midanterior margin, extending to ribbed postero-dorsal node, while the ventro-lateral rib extends from antero-ventral margin along poorly inflated alae terminating immediately below ventral margin at a prominent postero-ventral node. Well formed dorsal flange extends from anterior to posterior cardinal angles in right valves. Inner lamella broad anteriorly and posteriorly. Inner margin coincides with line of concresence. Radial pore canals not observed. Hinge lophodont. Muscle scar pattern not observed.

Dimensions. Length $360-385 \mu \mathrm{m}$, height $180-195 \mu \mathrm{m}$.

Distribution. At present, only recovered from the type locality, samples 104-113, beds 23-33, jamesoni-margaritatus Zones, Lower to Upper Pliensbachian.

Remarks. This species is similar to Eucytherura transversiplicata (Bate \& Coleman, 1975) recorded from the Toarcian and Aalenian of northwest Europe, but differs in the possession of a ribbed postero-dorsal node and a very prominent posteroventral node. Eucytherura batei (Ainsworth, 1986), is also similar, but can be distinguished by the absence of the oblique central rib, postero-ventral node and postero-dorsal node.

\section{CONCLUSIONS}

1. In the light of more recent studies on Lower Jurassic Ostracoda, a re-examination has been undertaken on the Pliensbachian and Toarcian Ostracoda first described by Exton (1979) from the Lusitanian Basin, west-central Portugal. Eighty species of Ostracoda have now been recognised, of which two species are newly described (Eucytherura zambujalensis sp. nov., Ektyphocythere mediodepressa sp. nov.). Poor preservation precludes a complete taxonomic review of the present material. Many of the assemblages possess strong similarities to those described from Northeast Spain, France, Germany, southern England and to a lesser extent to those described from the Fastnet Basin.

2. Five ostracod zones have been proposed; Gammacythere ubiquita-Ogmoconchella gruendeli Zone (Lower Pliensbachian), Polycope cerasia-P. cincinnata Zone (Uppermost Lower-lower Upper Pliensbachian), Liasina lanceolata-Ogmoconcha convexa Zone (uppermost Pliensbachian-lower- most Toarcian), Bairdiacypris rectangularis-Kinkelinella sermoisensis Zone (Lower-lowermost Middle Toarcian), and Cytherella toarcensis-Kinkelinella costata Zone (Uppermost Middle-Upper Toarcian).

3. An analysis of the ostracod assemblages from the Zambujal sequence has revealed fluctuations in the faunal composition which almost certainly reflect environmental changes, although at this point their interpretation remains uncertain. One distinct episode in the Late Pliensbachian led to the temporary dominance of the Cladocopina, a steady rise which is followed by a steady fall. The significance of this is uncertain since no modern of fossil analogues are known. The most significant change in faunal composition is the event which brought about the extinction of the Metacopina during the semicelatum subzone, the lower subzone of the tenuicostatum Zone of Early Toarcian age. This extinction event is similar to that which occurs throughout much of Northwest Europe at this time. Further work is required to fully understand the causes of this important event. The niche vacated by the Metacopina appears to have been initially filled by the Bairdiacea and later the Platycopina.

\section{ACKNOWLEDGEMENTS}

The authors would like to thank Dr Kevin Page of English Nature, Peterbrough for the identification of the Portuguese ammonites and his helpful discussions on Early Jurassic ammonite stratigraphy and also to $\mathrm{Mr}$ Richard Jones from University College of Wales, Aberystwyth, for the scanning electron microscope work.

\section{Manuscript received April 1995 Manuscript accepted May 1996}

\section{REFERENCES}

Ainsworth, N. R. 1986. Toarcian Ostracoda from the Fastnet Basin, offshore southwest Ireland. Bulletin of the Geological Survey of Ireland, 3: 277-336.

Ainsworth, N. R. 1987. Pliensbachian Ostracoda from the Fastnet Basin, offshore southwest Ireland. Bulletin of the Geological Survey of Ireland, 4: 41-62.

Ainsworth, N. R. \& Horton, N. F. 1986. Mesozoic micropalaeontology of exploration well Elf 55/30-1 from the Fastnet Basin, offshore southwest Ireland. Journal of Micropalaeontology, 5: 19-29.

Ainsworth, N. R., O'Neill, M. \& Rutherford, M. M. 1989. Jurassic and Upper Triassic biostratigraphy of the North Celtic Sea and Fastnet Basins. In Batten, D. \& Keen, M. C. (Eds), Northwest European Micropalaeontology and Palynology, 1-44, Ellis Horwood, Chichester.

Arias, C. \& Comas-Rengifo, M. J. 1992. Ostracodos del Domeriense Superior y Toarciense Inferior de la Cordillera Iberica. Revista Española de Micropaleontologia, 23: 111-155.

Arias, C., Comas-Rengifo, M. J., Goy, A., Herrero, C. \& Ruget, C. 1992. Variations dans les associations des brachiopodes, foraminiferes et ostracodes du Toarcien basal dans un secteur central de la cordillere iberique. Un exemple dans la "rambla del salto" (Teruel, Espange). Cahiers Scientifiques del Université Catholique de Lyon, 5: 5-25.

Bate, R. H. \& Coleman, B. E. 1975. Upper Lias Ostracoda from Rutland and Huntingdonshire. Bulletin of the Geological Survey of Great Britain, 55: 1-42.

Bodergat, A. M. \& Donze, P. 1988. Biostratigraphical scale in the Toarcian of the Paris Basin (France) by means of ostracod associations. In Hanai, T., Ikeya, N. \& Ishizaki, K. (Eds), Proceedings of the Ninth International Symposium on Ostracoda. Evolutionary Biology of Ostracoda, its Fundamentals and Applications, 1261-1267. Kodansha, Tokyo, Japan. 
Bate, R. H., Lord, A. R. \& Riegraf, W. 1984. Jurassic Ostracoda from Leg 79, Site 547. Initial Reports of the Deep Sea Drilling Project, 79: 703-710.

Boomer, I. D. 1988. On Ektyphocythere anterocosta Boomer sp. nov. A Stereo-Atlas of Ostracod Shells, 15: 93-96.

Boomer, I. D. 1991. Lower Jurassic ostracod biozonation of the Mochras Borehole. Journal of Micropalaeontology, 9: 205-218.

Boomer, I. D. 1992. Lower Jurassic ostracods from Illminster, Somerset, England. Journal of Micropalaeontology, 11: 47-57.

Boomer, I. D. \& Lord, A. R. 1988. On Ektyphocythere quadrata Boomer, sp. nov. A Stereo-Atlas of Ostracod Shells, 15: 85-88.

Boomer, I. D. \& Ainsworth, N. R. In press. The Early Jurassic. In Athersuch, J., Keen, M.C. \& Wilkinson, I. (Eds), A Stratigraphical Index of British Ostracoda. Chapman \& Hall, London.

Boomer, I. \& Whatley, R. 1992. Ostracoda and dysaerobia in the Lowe Jurassic of Wales: the reconstruction of past oxygen levels Palaeogeography, Palaeoclimatology, Palaeoecology, 99: 373-379.

Dépêche, F. 1985. Lias Supérieur, Dogger, Malm. In Oertli, H. J. (Ed.), Atlas des Ostracodes de France. Bulletin des Centres de Recherches Exploration-Production Elf Aquitaine, Mémoires, 9: 119-145.

Donze, P. 1985. Lias Inférieur et Moyen. In Oertli, H. J. (Ed.), Atlas des Ostracodes de France. Bulletin des Centres de Recherches Exploration -Production Elf Aquitaine, Mémoires, 9: 101-117.

Exton, J. 1979. Pliensbachian and Toarcian Microfaunas of Zambujal, Portugal: Systematic Paleontology. Geological Paper, Carleton University, Ottawa, 79: 1-104.

Exton, J. \& Gradstein, F. 1984. Early Jurassic Stratigraphy and micropalaeontology of the Grand Banks and Portugal. Geological Association of Canada Special Paper, 27: 13--30.

Harloff, J. 1993. Ostracoden des Unter-Pliensbachiums in BadenWürttenberg. Stuttgarter Beiträge zur Naturkunde, Serie B (Geologie und Paläontologie), 191: 1-215.

Herrig, E. 1979. Die Gattung Bairdia (Ostracoda, Crustacea) im Lias von Thüringen. Teil 1. Zeitschrift für Geologische Wissenschaften, 7: 641-661.

Joy, J. A. \& Clark, D. L. 1974. The distribution, ecology and systematics of the benthic Ostracoda of the central Arctic Ocean. Micropaleontology, 23: 129-154.

Knitter, H. 1983. Biostratigraphische Untersuchungen mit Ostracoden im Toarcien Süddeutschlands. Facies, 8: 213-262.

Knitter, H. 1984. Nomenklatorische Bemerkungen zu einigen Ostraco- denarten aus dem oberen Lias Süddeutschlands. Jahresheft. Geologisches Landesamt in Baden Württemberg, 26: 49-55.

Knitter, H. \& Riegraf, W. 1984. Biostratigraphie (Cephalopoden, Ostracoden) des Oberen Toarcium von Blumberg-Achdorf/Wutach und Weilheim/Teck (Baden-Württemberg). Jahresheft. Geologisches Landesamt in Baden Württemberg, 26: 57-97.

Lord, A. R. 1988. Ostracoda of the Early Jurassic Tethyan Ocean. In Hanai, T., Ikeya, N. \& Ishizaki, K. (Eds), Proceedings of the Ninth International Symposium on Ostracoda. Evolutionary biology of Ostracoda, its Fundamentals and Applications, 855-868. Kodansha, Tokyo, Japan.

Malz, H. 1975. Eine Entwicklungsreihe "vallater" Ogmoconchen (Ostracoda) im S-deutschen Lias. Senckenbergiana Lethaea, 55: 485 503.

Mouterde, R. 1955. Le Lias de Peniche. Communicacoes dos Servicos Geologicos de Portugal, 36: 87-115.

Mouterde, R., Ruget, C. \& Moitinho de Almeida, F. 1964. Coupe du Lias au sud de Condeixa. Communicacoes dos Servicos Geologicos de Portugal, 48: 16-91.

Mouterde, R., Rocha, R. B. \& Ruget, C. 1971. Le Lias Moyen et Súperieur de la Région de Tomar. Communicacoes dos Servicos Geologicos de Portugal, 55: 50-80.

Page, K. in press. The Lower Jurassic of Europe - its subdivision and correlation. In Surlik, F., Dybkjer, K., Inason, J., Nielsen, L. H. \& Poulson, N. E. (Eds). The Jurassic of Denmark and adjacent areas. Special Volume of the Geological Survey of Denmark.

Park, S. M. 1987. The ostracod zones and subzones of the Lower Jurassic in the southern North Sea Basin. Journal of the Paleontological Society, Korea, 1: 44-70.

Park, S. M. 1988. Evolutionary lineages of some stratigraphically important taxa from the Lower Jurassic of North-West Europe. Journal of the Paleontological Society, Korea, 4: 110-118.

Riegraf, W. 1984. Neue Ostracoden-Arten aus dem Oberem Pliensbachium und Unteren Toarcium Südwestdeutschlands und Südfrankreichs. Stuttgarter Beiträge zur Naturkunde, Serie B (Geologie und Paläontologie), 104: 1-19.

Riegraf, W. 1985. Mikrofauna, Biostratigraphie und Fazies im Unteren Toarcian Südwestdeutschlands und Vergleiche mit benachbarten Gebieten. Tübinger Mikropaläontogische Mitteilungen, 3: 1-232.

Whatley, R. C. 1991. The platycopid signal: a means of detecting kenoxic events using Ostracoda. Journal of Micropalaeontology, 10: $181-185$ 